\title{
5.2 Соціально-педагогічний портрет неповнолітніх залучених до комерційного сексу
}

Проституція як соціальне явище, властиве практично всім історичним формам громадської організації, виникло в найдавніші часи і зберігається до наших днів. Вона $є, з$ одного боку, загальновизнаним негативним соціальним феноменом, з іншого боку, надзвичайно прибутковим і легальним в багатьох країнах бізнесом. У світі існує величезний ринок секс-бізнесу, у тому числі дитячого, він приносить великі прибутки.

Особливе соціальне загострення це явище набуло у зв'язку з тим, що комерційний секс став одним із шляхів поширення СНІДу. Крім того, проституція «молодшає» - в сферу секс-бізнесу все активніше залучаються неповнолітні.

Визначень проституції існує багато. Термін «проституція» походить від лат. слова prostitutio, що означає осквернення, збезчещення, або prostituere виставляти привселюдно (Балакірєва О., Бондар Т., Сазонова Я., Сакович О., 2018; Протопопов А., Савельєва Н., 2009).

Проституцію можна визначити як надання сексуальних послуг за гроші (Гіденс Е., 1999). Крім того, проституція - це залучення до безладних статевих відносин інших осіб, окрім подружжя, в обмін на негайну оплату грошима чи іншими цінними речами (Мінц М., 2009); проституція - це здійснення статевих актів за винагороду; проституція - це надання жінкою свого тіла за винагороду особам, які шукають задоволення статевого бажання. На думку української науковиці І. Д. Звєрєвої, «проституція - це сфера знеособлених емоційно, позашлюбних, безладних, здійснюваних за плату статевих стосунків» (Звєрєва I., Безпалько О., Марченко С., 2004).

Дитяча проституція - проституція осіб віком до 18 років. У переважній більшості держав переслідується законодавством. Додатковий протокол до Конвенції про права дитини, що стосується торгівлі дітьми, дитячої проституції та дитячої порнографії, визначають дитячу проституцію як «практику, коли 
дитина використовується 3 метою отримання сексуальних послуг особами за винагороду або будь-яку іншу форму компенсації» (стаття 2b) (Факультативний протокол до Конвенції про права дитини щодо торгівлі дітьми, дитячої проституції і дитячої порнографії, 2000).

В Україні феномен проституції є недостатньо вивченим. Починаючи із 30х років ХХ ст., усі дослідження цієї проблеми у колишньому СРСР було припинено. Лише наприкінці 80-х років минулого століття проституцію було офіційно визнано соціальним явищем (Протопопов А., Савельєва Н., 2009).

На сучасному етапі розвитку суспільних наук при обговоренні даної тематики, крім терміну «проституція», все частіше використовується термін «сексуальний бізнес», «комерційний секс», тобто продаж сексуальних послуг, під якими мається на увазі не тільки наявність статевого акту, але і сексуально забарвлене спілкування, мастурбація тощо.

Згідно даних Українського інституту соціальних досліджень ім. О. Яременка, серед жінок, які займаються наданням сексуальних послуг в комерційних цілях, 11\% складали діти у віці від 12 до 15 років і 20\% - у віці від 16 до 17 років (Балакірєва О., Бондар Т., Галустян Ю., 2012).

Згідно 3 даними біоповедінкових досліджень цього ж Українського інституту соціальних досліджень ім. О. Яременка та ЮНІСЕФ (2013-2014 рр.) серед 123,5 тис. дітей, що належать до груп ризику, і дітей вулиці, кількість дівчат, які надають сексуальні послуги на комерційній основі, склала 5,5 тис., кількість хлопчиків-підлітків, які мали секс з чоловіками, склала 13 тис. (Балакірєва О., Бондар Т., Сазонова Я., Сакович О., 2018).

За оціночними даними соціологів, в 2011 році в Україні до комерційного сексу було залучено близько 110 тисяч жінок. За інформацією О. Балакірєвої, кожна шоста-сьома повія - неповнолітня.

Один 3 важливих питань дискусії навколо причин залучення до комерційного сексу та факторів, що сприяють цьому активно обговорюється роль перенесеного в дитинстві насильства. Численні дослідження показали, що психічні травми дитинства впливають на все подальше життя людини, 
формування характеру, психічне і фізичне здоров'я. Увагу дослідників все більше привертає феномен жорстокого поводження і домашнього насильства щодо дітей. Найбільш прихованим видом жорстокого поводження 3 дітьми $\epsilon$ сексуальне насильство, яке нерідко призводить до виникнення специфічних розладів.

Сексуальне насильство щодо дитини як форма домашнього насильства включає: будь-які діяння сексуального характеру, вчинені стосовно дитини незалежно від іiі згоди або в присутності дитини; примушування дитини до акту сексуального характеру з третьою особою; інші правопорушення проти статевої свободи чи статевої недоторканості особи, у тому числі вчинені стосовно дитини або в її присутності (п. 15 ч. 1 ст. 1 Закону України «Про запобігання та протидії домашньому насильству», 2017).

За офіційною статистикою у 2020 році 320 дітей в Україні зазнали сексуального насильства. На жаль, реальна кількість постраждалих у рази більша.

Згідно із дослідженнями Ради Європи кожна п’ята дитина в Україні стала жертвою різних форм сексуального насильства (від розбещення до згвалтування).

Поширеність сексуального насильства над дітьми в світі оцінюється близько $20 \%$ у дівчат і приблизно $8 \%$ у хлопців. За наявними даними найбільш високий рівень сексуального насильства над дітьми в Африці (близько 35\%), найнижчий в Свропі (9\%).

Дитячий фонд ООН (ЮНІСЕФ) представив результати дослідження «Комплексна оцінка масштабів продажу дітей, дитячої проституції та порнографії в Україні». Дослідження виявило, що основними групами дітей, які характеризуються підвищеним ризиком постраждати від дитячої проституції, порнографії та торгівлі дітьми є безпритульні, бездоглядні діти, з багатодітних, соціально-деструктивних, неповних, малозабезпечених сімей; діти віком від 13 років і старше. Опитування дітей 14-18 років виявило наступне: $11 \%$ показували своє голе тіло; 10,4\% дозволяли торкнутися до голих частин свого тіла (ощупати 
себе); 7,8\% займалися сексом за певну плату; 3,2\% погоджувалися сфотографуватися або знятися у фільмі в оголеному вигляд.

Також було показано, що серед дітей лише $34,4 \%$ опитаних мають обох батьків; впродовж останніх трьох місяців лише 11,7\% проживали 3 обома батьками, більшість дітей (58,4\%) описують свою сім'ю як дуже бідну, 31,8\% опитаних дітей ніде не навчаються. Основна причина, через яку вони не навчаються, є небажання вчитися, відсутність цікавості до навчання (40,5\%), 14,8\% дітей змушені замість навчання працювати, 11,2\% вважають, що краще працювати, ніж навчатися, 8,9\% батьки не дозволяють їм вчитися (Комерційна сексуальна експлуатація дітей і підлітків, 2011; Шиделко А., 2011).

Дівчата, що стоять на трасах, кільцевих дорогах та обслуговують водіївдалекобійників, отримують за секс-послугу 5 доларів. Крім дівчат, трапляються і хлопчики до 13 років, які також надають послуги водіям. Як причину роботи в проституції діти називають «бажання вижити», «мати гроші на якусь річ» та «необхідність допомагати батькам» (Швед О., 2005).

За даними досліджень, проведених Фондом Нічиї Діти в 2011 році, 24\% респондентів у віці 15-18 років заявили, що вони особисто знають принаймні одну людину, яка в минулому році була в контакті чи пов'язана сексуальними відносинами за гроші або інші подарунки (Комерційна сексуальна експлуатація дітей і підлітків, 2011).

Відповідно до інформації Українського інституту соціальних досліджень ім. О. Яременка та ЮНІСЕФ (2017-2018 рр.) серед 109 тис. дітей віком від 10 до 19 років включно, що належать до груп ризику, і дітей вулиці, кількість дівчат, які надають сексуальні послуги на комерційній основі, склала 5 тис., кількість хлопчиків-підлітків, які мали секс 3 чоловіками, склала 21,3 тис. Також показано, що у 2017 р. частка підлітків, які починають надавати сексуальні послуги за винагороду до досягнення 15 років, зменшується (у порівнянні з 2007 р.). Дещо зменшилась також й частка дівчат, які починають надавати сексуальні послуги за винагороду до досягнення повноліття (Балакірєва О., Бондар Т., Сазонова Я., Сакович О., 2018). 
Військовий конфлікт на Донбасі аналогічно посприяв поширенню такого явища. Відомі навіть випадки, коли дівчата пропонували секс в обмін на продукти харчування.

Крім того, в сучасній Україні проявилось таке явище як соціальне сирітство, коли батьки поїхали закордон на заробітки, покинувши своїх дітейпідлітків або самих, або на стареньких батьків. Ці діти зростають без батьківської уваги і вештаються вулицями тільки тому, що вдома нікого нема. На них легко впливати, чинити тиск через ще несформований характер (Тимків Н., 2019).

Спосіб життя неповнолітніх, які займаються проституцією, є достатньо безладний. Нерегулярність і неправильність харчування, хронічна втома, нервові перевантаження, насилля, вживання алкоголю, наркотиків та паління, інфекційні захворювання, мають руйнівний вплив на фізичне та психічне здоров'я підлітків. Такі діти $є$ потенційним джерелом інфекцій: венеричних захворювань, туберкульозу, гепатитів В і C, ВІЛ-інфекції тощо. Певна частина даної категорії дітей вживають алкоголь і наркотичні речовини з метою зниження тривожності, хвилювання, зняття депресивного стану і роздратованості, що, в свою чергу, породжує фізичну та психічну залежність з усіма наслідками (Протопопов А., Савельєва Н., 2009).

Поведінка дітей, що до комерційного сексу, принципово відрізняється від поведінки дорослих повій. До числа найбільш характерних відмінностей відносять наступні.

- Неусвідомленість своїх вчинків. На відміну від дорослих повій, які усвідомлено і цілеспрямовано ведуть антисоціальний спосіб життя для отримання доходу, у дітей в якості основних мотивів заняття проституцією виступають такі, як прагнення до самоствердження, цікавість, бажання виглядати дорослими.

- Отримання оплати за свою працю в різних формах. Якщо дорослі повії винагороду за свою працю отримують, як правило, виключно в грошовому вираженні, то з дітьми часто розраховуються речами, косметикою, спиртними напоями, вечерею в ресторані, сигаретами тощо. 
- Продаж свого тіла в будь-якому місці за бажанням статевого партнера. Дорослі повії зазвичай мають для надання сексуальних послуг певні умови (знімається постійна квартира, місця в готелях тощо), тоді як діти займаються проституцією переважно на вокзалах, в салонах автомобілів, підвалах, під'їздах, на горищах тощо.

- Споживання дитиною при наданні сексуальних послуг великих доз алкоголю або наркотичних речовин. Діти нерідко змушені пити зі своїм клієнтом якомога більше для того, щоб обпоїти останнього з метою пограбування.

- Заняття проституцією з вимушеною перервою, оскільки час від часу діти потрапляють, наприклад, в притулки або примусово повертаються до батьків.

- Залякування, шантажування підлітка можливим оприлюдненням щодо заняття проституцією перед групою однолітків, батьками або шкільним колективом у разі відмови займатися цим видом діяльності.

- Правовий нігілізм підлітків, який полягає в тому, що в число друзів підлітка, як правило, входять кримінальні елементи: спекулянти, валютники, наркомани, сутенери, але нікого 3 них вони не вважають злочинцями і не пов'язують себе з злочинним світом.

Особливості дитячої проституції полягають в тому, що в більшості випадків діти не усвідомлюють правильності своїх вчинків (Протопопов А., Савельєва Н., 2009).

Проституція неповнолітніх стала справжньою галуззю тіньової економіки, яка приносить великі прибутки організованим злочинним угрупованням. Розповсюдження й експлуатація дитячої порнографії - проблема світового рівня. Одним із сучасних засобів передачі продукції дитячої порнографії $\epsilon$ розповсюдження її каналами міжнародної комп'ютерної мережі Інтернет (Швед O., 2005).

Проведене нами дослідження щодо обізнаності сучасних підлітків щодо ризиків залучення до комерційного сексу вказує на те, що підлітки не розуміють, які існують ризики щодо залучення до комерційного сексу. Були опитані 644 особи, а саме, учні/учениці 8-9 класів. Наведемо деякі результати. 
Що стосується проблеми комерційного сексу, то ми поцікавилися у респондентів, чи знають вони, що таке комерційний секс. Більшість досліджуваних вважають, що комерційний секс - це проституція, секс за гроші, шлях отримання матеріальних благ, винагорода за матеріальні цінності. Багато респондентів зазначають, що комерційний секс робота, за яку потрібно достойно платити. Також, частина опитаних не знають або не розуміють, що означає дане поняття.

Важливим для нас було дізнатися думку дітей щодо чинників, через які діти та підлітки до 18 років вступають в сексуальні контакти за винагороду або будь-яку іншу форму компенсації (рис. 1). Аналіз відповідей респондентів показує, що більшість опитаних (301) вважають, що продають себе тому, що вони хочуть мати модний одяг, косметику, аксесуари, тобто вони допускають, що проституція може бути таким джерелом доходу, і що при певних обставинах надали б сексуальні послуги за винагороду в обмін на модний одяг, косметику, аксесуари. 300 осіб зазначили, що однією із причин може бути бажання справити враження на однолітків. Показово, що серед учнів/учениць велика кількість тих, хто вважає, що практикувати участь в сексуальній активності в обмін на плату через цікавість, бажання пережити пригоди та отримання задоволення від сексу (260 та 219 відповідно). 242 і 102 вказують на те, що до такого роду діяльності змушує тяжка життєва ситуація або примус з боку інших осіб, тобто вони розуміють, що сексуальне зловживання відносно дитини з боку дорослої особи за винагороду є неприпустимим. Зокрема, варіант відповіді «Не знаю/важко сказати» вибрали 104 юнаків/юнок. 
Не знаю/важко сказати 104

Тому, що вони хочуть отримувати задоволення від сексу

Тому, що їх примусили інші

Бажання справити враження на однолітків

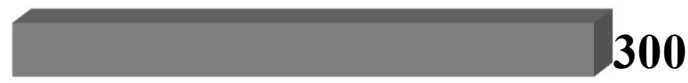

Цікавість, бажання пережити пригоди 260

Тому, що змушує їх тяжка життєва ситуація 242

Тому, що вони хочуть мати модний одяг, косметику, аксесуари

Рисунок 1. Чому, на твою думку, діти та підлітки до 18 років вступають у сексуальні контакти за винагороду або будь-яку іншу форму компенсації?

Аналізуючи відповіді респондентів на запитання: «В яких групах дітей та молоді існус великий ризик, що вони вступатимуть в статевий контакт за винагороду або будь-яку іншу форму компенсації?» (рис. 2), ми дійшли висновку, що переважна більшість учнів/учениць (600) вважають, що саме у дітей і підлітків з сімей у складних життєвих обставинах, сімей з проблемами (наприклад, алкоголь, наркотики, насильство) та 3 малозабезпечених сімей може існувати великий ризик, що вони вступатимуть в статевий контакт за винагороду або будь-яку іншу форму компенсації. На те, що у дітей та підлітків з сімей, де батьки не мають часу для своїх дітей і де батьки не говорять зі своїми дітьми про секс також є великий ризик, що вони вступатимуть в статевий контакт за винагороду або будь-яку іншу форму компенсації зазначили 238 і 183 опитаних відповідно. 183 підлітків відповіли, що люди, над якими було здійснене насильство, в тому числі сексуальне, в дитинстві можуть в подальшому надавати сексуальні послуги за винагороду, тобто сексуальні 
посягання вважаються причиною того, що діти в майбутньому будуть займаються проституцією.

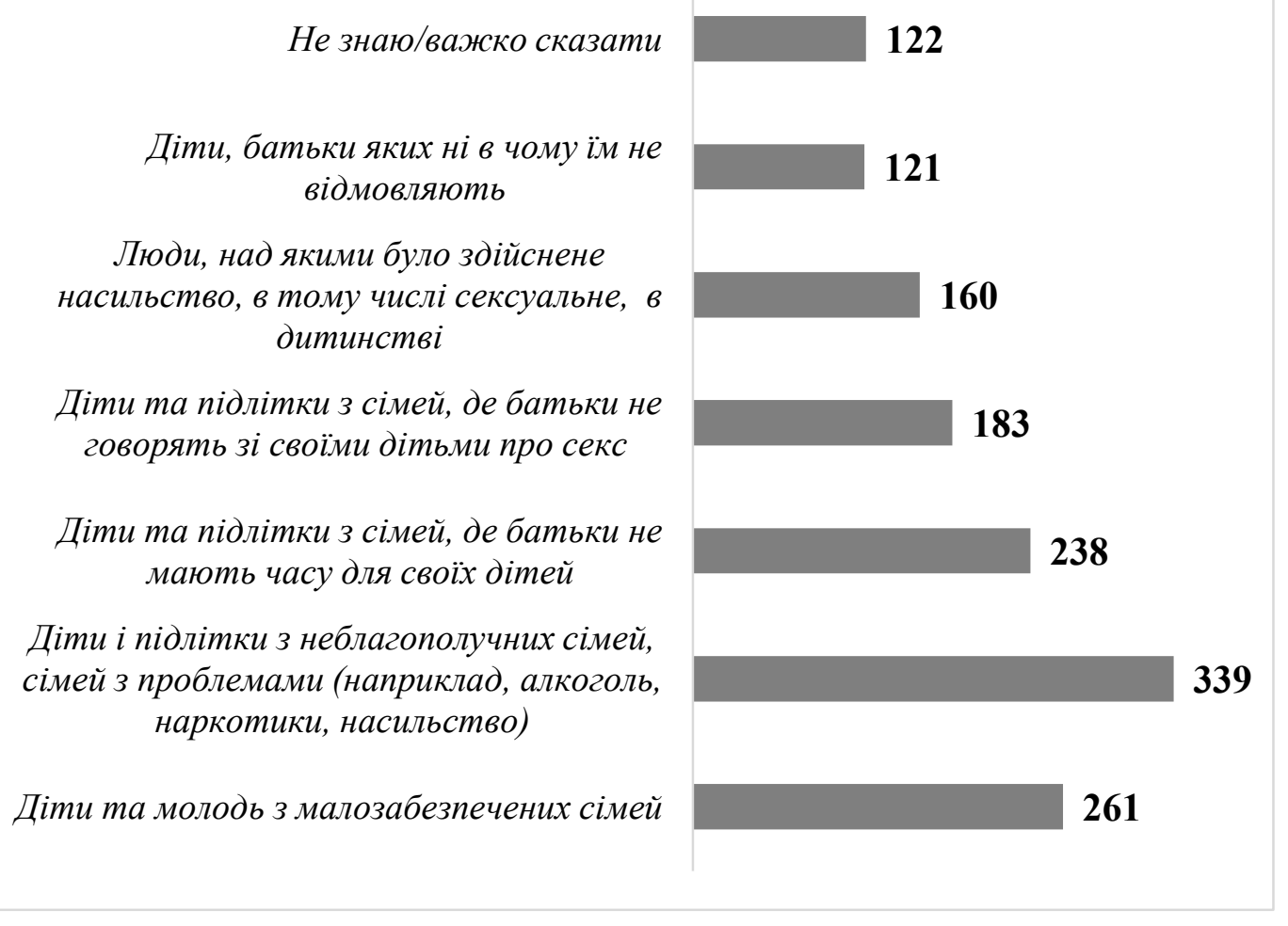

Рисунок 2. В яких групах дітей та молоді існує великий ризик, що вони вступатимуть в статевий контакт за винагороду або будь-яку іншу форму компенсації?

Наступний блок запитань стосувався позитивних і негативних моментів проблеми проституції (рис. 3, 4). Отримані дані показали, що до позитивних моментів комерційного сексу підлітки відносять задоволення сексуальної потреби людей, які живуть без партнера/партнерки, осіб з особливими потребами (424), зняття сексуальної напруги (180) та компенсація і доповнення до сексуальної активності (98). 161 учасник дослідження не знають, що відноситься до позитивних моментів проституції, тобто, вони засуджують такий вид діяльності. Негативним моментами, на думку, підлітків $\epsilon$ поширення інфекційних венеричних захворювань, ВІЛ/СНІДу (544), збільшення кількості абортів (380), зміна психіки в осіб, які займаються проституцією (239), втрата здатності до нормального шлюбу і материнства (221), поширення алкоголізму і наркоманії у зв'язку з високими емоційними стресами (181). 


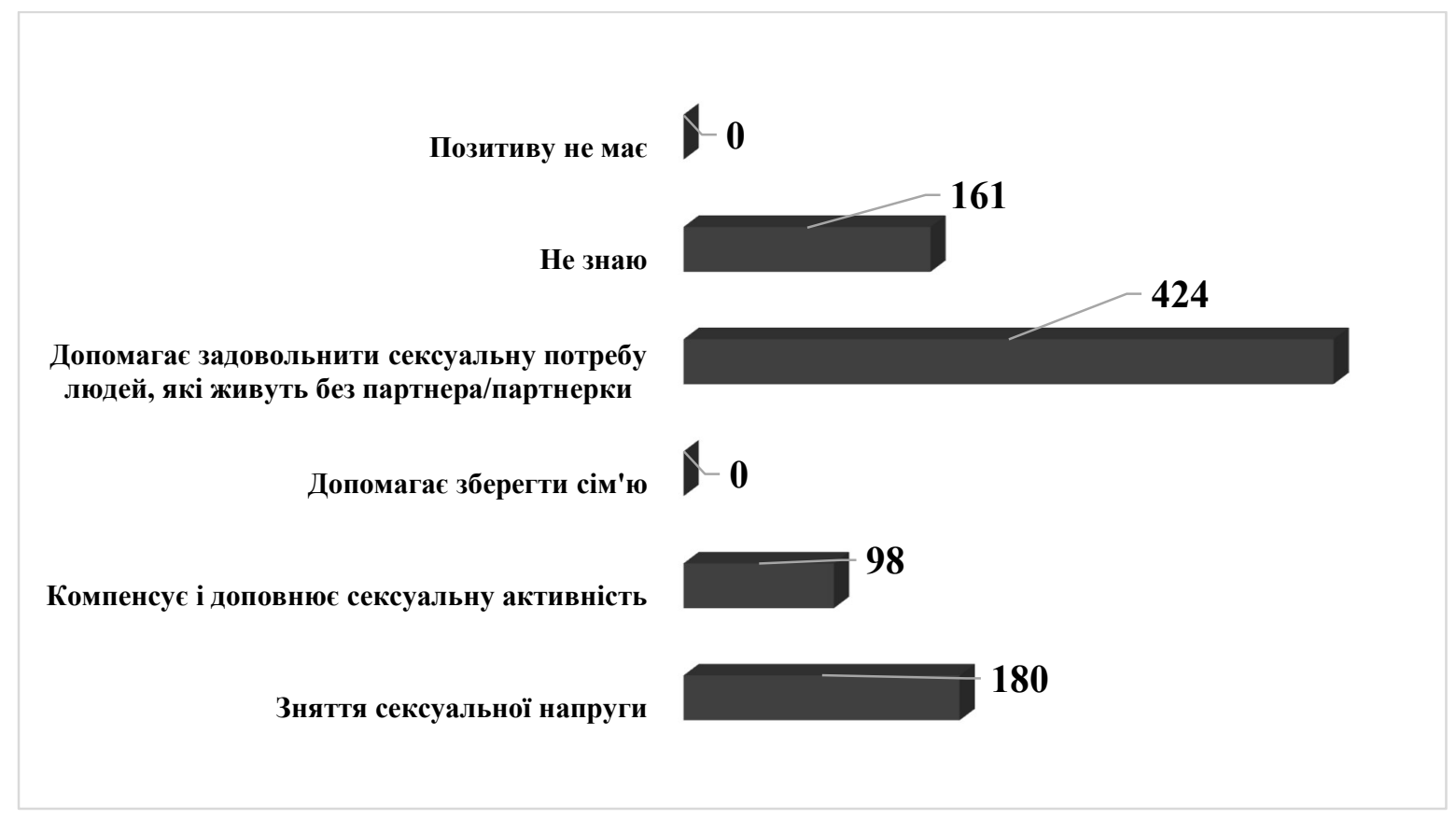

Рисунок 3. Позитивні моменти проституції

Негативних наслідків не мас

Не знаю

Збільшення кількості абортів

Поширення інфекційних венеричних захворювань, ВІЛ/СНІДу

Поширення алкоголізму і наркоманії, у зв' язку з високими емоційними стресами

Зміна психіки в осіб, які займаються проституцісю

Втрата здатності до нормального шлюбу i материнства

121 380
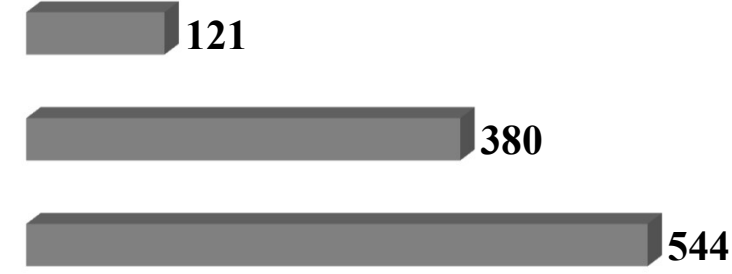

180

239

221

Рисунок 3. Негативні наслідки проституції

Отже, проаналізувавши отримані результати і узагальнивши дані, можна зробити висновок, що, на думку учнів/учениць, саме у дітей і підлітків з сімей у складних життєвих обставинах, сімей з проблемами (наприклад, алкоголь, наркотики, насильство) та з малозабезпечених сімей може існувати великий 
ризик, що вони вступатимуть в статевий контакт за винагороду або будь-яку іншу форму компенсації. Причинами, які, на думку, респондентів, можуть сприяти залученню підлітків до комерційного сексу є низький рівень доходів сім'ї , бідність, борги, нестача грошей, відсутність постійної роботи може спричинити залучення у сферу секс-бізнесу.

На жаль, в Україні надання секс-послуг дитиною старше 16 років (дитиною, яка досягла статевої зрілості) не є злочином. Проте міжнародні стандарти показують, що криміналізація купівлі секс-послуги від дитини може зменшити попит на дитячу проституцію, що відповідно зменшує пропозицію, i, як наслідок, кількість дітей-жертв сексуальної експлуатації. 